Revista Iberoamericana, Vol. LXIX, Núm. 202, Enero-Marzo 2003, 51-63

\title{
LA VIDA REAL Y EL SUCESO DE LA IMPOSTACIÓN: EL ESCENARIO PANÓPTICO DE GRAN HERMANO
}

\author{
POR \\ EDUARDo EsPINA \\ Texas A\&M University
}

El miércoles 19 de diciembre de 2001, el diario El Observador de Montevideo publicó una carta contraria a los reality shows. La carta estaba firmada por más de cuatrocientas personas. No era la primera misiva —ni será la última — en destacar el contenido denigrante de los programas de televisión que dicen promover "la vida en vivo y en directo”. Ejemplo de una cruzada minoritaria (la mayoría es adicta a este tipo de entretenimiento) contra la pauperización de los esquemas y conceptos televisivos, la carta mancomunada decía:

\begin{abstract}
En momentos que desde el gobierno se habla de promover en las familias y en las escuelas la educación en los valores morales, constatamos con espanto e indignación los reality shows que actualmente están transmitiendo en TV que son el polo opuesto de aquello que se quiere alcanzar. El pueblo uruguayo que siempre tuvo un buen nivel moral y cultural ha ido perdiendo su identidad. Estos programas “importados” además de ser inmorales, están fuera de la realidad con situaciones rebuscadas y un lenguaje que exagera la grosería y sin ningún valor artístico. ¿Estamos tan mal que por el rating y la competencia de los canales, entre en nuestras casas esto que desearíamos que nadie en nuestra familia lo viera?
\end{abstract}

Desde el debut de Gran hermano español, el 10 de enero de 2001, los reality shows proliferan en la televisión uruguaya, casi todos ellos provenientes de España y Argentina, sobre todo Argentina: son menos costosos que una serie policial estadounidense y generan en el presente mejores ratings. Televisión pobre a bajo costo: ideal para tiempos todavía más pobres. ${ }^{1}$ La presencia en Uruguay de este formato, tanto en versión española como

\footnotetext{
${ }^{1}$ Gran hermano se importa de España y Argentina pues los canales uruguayos dijeron que salía muy caro producirlo en el país. Los derechos de televisación y los costos de producción impedirían tener ganancias. En uno de los canales informaron: “¿Para qué vamos a hacer algo que ya está hecho?”. En otro: "Acá es imposible que lo haga cualquier canal por un problema de infraestructura. Tenés que montar todo otro canal afuera y no dan los números". Sin embargo, aunque producir Gran hermano pueda resultar costoso para los canales uruguayos, para los estándares televisivos de Europa y Estados Unidos es un concepto nada complicado de producir. Un ciclo completo de Gran hermano cuesta mucho menos que un sólo capítulo de Friends, ER o cualquier otra serial estadounidense exitosa.
} 
argentina, ha sido un fenómeno massmediático construido a partir de la necesidad de generar audiencia a cualquier costo (que sea bajo). A fines de 2000, con la angustia anticipada del fin de milenio, los programadores televisivos uruguayos enfrentaban el mismo dilema que sus pares europeos y estadounidenses tuvieron varios meses antes: la caída de los registros de audiencia y el desinterés ante los programas “tradicionales”, es decir, aquellos que aún basan su estructura en una anécdota con resolución y en el trabajo orquestador de un guionista.

Los gustos y preferencias en la escena del entretenimiento cambiaron radicalmente en el tiempo bisagra entre ambos siglos, aunque pocos fueron capaces de prever los desplazamientos de prioridades para que éstas estuvieran a la altura del share y del rating. Se necesitaba una excusa ganadora en los horarios centrales, allí donde los programas tradicionales - telenovelas y seriales — habían dejado de tener un impacto imperecedero. La televisión generalista había entrado en crisis y el zigzag de apetencias pronosticaba un desplome de las modalidades tradicionales y el surgimiento de nuevas expectativas identificadas con la inmediatez del producto. Como relleno, casi como vehículo transicional, llegó un experimento audiovisual sin antecedentes verificables, salvo en algunos ejemplos literarios y cinematográficos notorios. En televisión, con su alcance masivo, la idea resultaba novedosa y promovía una oferta diversificante de mercadotecnia; un estilo defectuoso pero sumamente efectivo.

El asunto se llamaba Gran hermano y venía —la idea — de Holanda. Funcionó rápidamente en varios países europeos: la multiexplotación de un contenido generalizado que establece afinidades que pueden ser asimiladas sin decisión ni condicionamiento de fronteras. El concepto no podía ser más básico: treinta cámaras — ciento setenta técnicos, camarógrafos, productores, editores - siguiendo durante veinticuatro horas por ciento doce días los sucesos domésticos de diez participantes intentando ganar doscientos mil dólares. "Hemos creado un nuevo género que descubre que las personas comunes y corrientes pueden ser interesantes”, dijo el creador del programa, el holandés John De Mol (Endemol Entertainment International), al estrenar su producto. No se trataba de un invento, era un "descubrimiento".

Verdadera taxidermia de un strip-tease colectivo, Gran hermano funcionó desde su comienzo como curiosidad. Para los televidentes uruguayos trajo ejemplos recientes de comportamientos a ras del suelo con los cuales — los números fueron extraordinariosla audiencia sintió una empatía inmediata sin importar el lugar de procedencia. Extrañamente - y una de las pautas de Gran hermano es que nada de lo humano debe resultar extrañola audiencia uruguaya sintonizó el programa por curiosidad y permaneció fiel al mismo por una suerte de impensable coincidencia mimética. Con su ráfaga de símbolos disecados pero en actividad, Gran hermano trajo la globalización del gusto a zonas permeables. La popularidad del formato en pantallas uruguayas, con su propia página en Internet (www.granhermano.com.uy), vino a confirmar la clonación de una experiencia colectiva. También el Sur profundo, aquel que Charles Darwin igualó al fin del mundo, sacó la geografía del living de su ostracismo: la televisión trajo el mismo fin — también como finalidad- para todos.

De Gran hermano se han hecho en el mundo dieciocho versiones y se calcula que cerca de seiscientos millones de personas han visto alguna vez el programa. Las cifras son 
más contundentes que las frases: Gran hermano I y II argentino fueron los dos programas más populares de la televisión uruguaya en el año 2001. Si eso dice algo, es esto: 1) La gente del país todavía mira televisión. 2) Los uruguayos prefieren programas de fácil consumo y que privilegian la homogeneización de conductas sociales a costo de su simplificación. 3) Gran hermano es una fraternidad internacional que no tiene demasiadas exigencias para aceptar a sus nuevos miembros. Los números, además de sorprendentes, pueden considerarse alarmantes: el sábado 30 de junio de 2001, cuando finalizó Gran hermano (I), nueve de cada diez televisores sintonizaron el programa. Un récord no igualado ni por la llegada del hombre a la Luna ni por ninguna final de la Copa del Mundo de fútbol.

La prensa dio cuenta de situaciones insólitas referidas a la repentina avidez nacional por sentirse hermanados en el juego interpersonal de conflictos y afectos: bodas que se postergaron hasta que finalizara el capítulo final; fiestas realizadas para celebrar la consagración del candidato favorito de la audiencia (Marcelo) como único ocupante de la casa que no fue desalojado; bares y restaurantes que colocaron televisores especialmente para que nadie se perdiera el programa. La descomposición del gusto popular tuvo carácter ciudadano; la propiedad de la intimidad salió a la calle: "El Gran hermano te vigila" (George Orwell en 1984). Los participantes, dentro de la casa del vigilante, no sabían lo que pasaba en el exterior (las cámaras no actuaron con reciprocidad), pero la audiencia creía saber lo que ocurría dentro y fuera de la casa: cada espectador se sentía parte destacada del ojo hispano-hablante de Big Brother. Una sociedad anónima de espías facilitó el juego de mirar sin ser mirado; de eso habría que culpar (o agradecer) a la intransitividad del espejo televisivo.

Entre el 23 de abril y el 30 de junio de 2001, un promedio de 372.300 uruguayos (la mayoría en la franja poblacional comprendida entre 30 y 39 años) vio ambas versiones argentinas de Gran hermano, emitido diariamente en varias ediciones; nueve horas semanales de programación, del total de 5.040 horas registradas por las cámaras. Una perpetuidad que pasó por un proceso de edición. Para vulnerar la atención, la estrategia partió de una falsificación del truco. La proliferación de cámaras reinventó con notoria facilidad un hecho cierto que no presentaba impedimentos para acceder a él. Entonces, la atracción irreflexiva resultó tributaria de una intimidad sensacionalista que pretendió hacer de la controversia una subversión y que imitó desfiguradamente a una realidad con sus propias pautas de verificación.

En la acumulación curricular de contenidos y síntomas de realidad mediante el polifocalismo, se estableció la farsa del avatar, en tanto el producto sufrió una selección previa y una edición posterior. Conspiración perfecta al servicio de una imitación no limitada por la repetitividad, la cual indefectiblemente terminó banalizando la vigilancia, convirtiéndola en un episodio de sus consecuencias. Es la complicidad —no retribuida— de vigilar y sentirse vigilado, de participar desde el lugar estratégico del living room de una táctica despersonalizante. En esa superficie de brillos (el resplandor no tiene dónde esconderse), el televidente uruguayo se sintió participante de una adición universal de datos y conductas que no exigen cualidades para poder realizarse. En este show de lo real en directo, también la emotividad salió escamoteada. De allí que nadie pudo sentirse extranjero en esa falta compartida de voluntad y ascenso de notoriedad instántanea. Desde 
su pasividad, el televidente compartió la rápida gloria de seres sin atributos artísticos, a quienes celebró por una simple razón: como la nueva estrella mediática carece de talento — salvo el de haberse dejado husmear sin pudor a costa de un premio no garantido_-, la nueva estrella bien podría ser el propio televidente. Ese soy yo. Desde su llegada, el peep show disolvió los límites del coto de caza y de aquello que se consideraba indecoroso como para ser compartido. En esas horas sin aura, la complicidad con la impudicia fue ejercida con el rubor a bajo volumen. No en vano, los habitantes actuaban con displicencia, como si no se sintieran vigilados, como si el culto de la apariencia no fuera un mal innecesario. Estaban allí, tendiendo a quedarse en sí mismos.

Así pues, la empatía (más allá de la hermandad rioplatense y de la relación edípica con la madre patria) se dio a nivel de carencias gregarias. La solidaridad de las carencias: el especímen observado era de la misma calaña que la audiencia. No está de más recordarlo, en todo esto hay una patología implícita —o no tanto— que se comparte. La sintonía dramática convierte al semejante en informador de lo que el espectador quiere ser. Así, el impacto de la inmediatez puede verificarse en las acciones voyeurísticas del televidente. La falta de densidad de los comportamientos en la casa de Gran hermano resultó a la postre un autorretrato nada escandalizador del público en el exterior, el cual estuvo de acuerdo incluso con la condición espasmódica, breve, del logro. Es que la apetencia por la instantaneidad de la fama, vive de lapsos irreciclables. Como si fuera la grabación de Misión imposible, la cinta del reconocimiento público se destruye — contra su voluntad - en un tiempo más corto que el prudencial. La construcción de la celebridad a bajo costo no tiene que esperar mucho tiempo para operarse. Apenas los participantes ejercen su vida antes las cámaras, el dividendo de la gloria queda a merced de su alcance. Y también su final. La clave de la convocatoria es el ofrecimiento de notoriedad acompañada de dinero. Y como las cosas están tan mal... Es la fama multiexplotada que dura poco, pero que también lleva poco tiempo edificarla: paradigma de una nueva forma de exposición incluida en un contenido pasajero. "Lujuria de los ojos” (Primera Epístola de San Juan, 2:16).

Antes, en el apogeo de la época moderna, la invisibilidad de la elusión era el signo victorioso de una libertad contra toda sospecha. Ser invisible significaba eludir la vigilancia. Ya no. Gobierna una exhaustiva visibilidad, cómplice con la manera obsesiva de sentirse superior en el acto de exposición pública, sabiendo anticipadamente que los detectives han sido detectados. A diferencia de Truman (The Truman Show), los protagonistas de Gran hermano “actúan de sí mismos” sabiendo que los están mirando del otro lado, donde ellos también están. ${ }^{2}$ Se trata de una observación no recíproca pero autorizada, que hace sentir más vivos a los observados, exultantemente vivos, pues están

\footnotetext{
${ }^{2}$ Las versiones europeas, latinoamericanas y estadounidenses de Gran Hermano varían básicamente en un punto fundamental: el comportamiento de los protagonistas ante las cámaras. Según Paul Romer, productor de la versión estadounidense, "en Big Brother, nuestros participantes nunca se olvidan que están frente a una cámara. En Europa se olvidan rápidamente que están frente a una cámara” (Fin de semana 356, año 5, 16 de junio de 2001, 2-3). En la versión argentina, los protagonistas se parecen a sus pares estadounidenses: son una imitación teatral de sí mismos; se muestran empeñados en construir sus sentimientos y en ser el centro de una atención totalitaria.
} 
en la observación constante y sin corregir de todos los demás, quienes los aceptan por lo que aún no pudieron ser y sin embargo hacen. Al desprotegerse ante fuerzas invasoras que son bienvenidas, el ego se siente acompañado, elegido para una asociación mutuamente perversa que resulta y que deja resultados.

En suma, es una parodia del gran juego de la infancia: la escondida. Tarde o demasiado temprano, todos serán descubiertos por los dioses omniscientes del control remoto. Hasta no hace mucho, en la era contemporánea, la privacidad resultaba una exigencia obligatoria. En esta, poscontemporánea (o el pos que sea), la fenomenología del exhibicionismo arrasó con los atavismos y anomalías de la timidez, fomentando el deseo de celebridad como forma extrema del instinto gregario. La indiferencia de los demás es lo que trae el descontento, lo que ocasiona la ruptura jerárquica con los patrones de autosatisfacción. Se trata pues, de ser la excepción integrándose mansamente a un teatro colectivo nada excepcional.

\section{LA CÁMARA COMO MICROSCOPIO}

Diariamente pasamos frente a obsesivas cámaras de televisión; en el trabajo, en el supermercado, en la biblioteca, en el lavadero, en el restorán: en donde el cuerpo esté. Les prestamos la misma atención que a un jarrón o a un cenicero. Ya se hicieron parte de la rutina. Según una reciente encuesta, en Estados Unidos el 74\% de las personas consultadas no ve con desagrado que lo estén controlando por televisión cerrada mientras trabaja. Se ganó libertad y se perdió intimidad. Antes los fisgones y husmeadores eran señalados con un dedo para mostrar su irrespetuosidad. Hoy el dedo aprieta solícito un botón para iniciar el espionaje. Los espías somos todos y es un orgullo serlo. El voyeurismo, tal como aparece en el filme La noche es mi enemiga de Patrice Leconte, ya no se considera enfermedad. En todo caso, es un mal contagioso del que nadie está inmune: el virus de la condición disminuida.

La televisión, mostrando su actual falta de inventiva, recurre en Gran hermano a la mediocridad de la vida diaria como vedette de un formato de entretenimiento popular en todo el mundo. Hace años hubo en Uruguay un programa llamado Venga y cante. El eslogan de Gran hermano bien podría ser: "Venga y haga ante las cámaras lo que no se atreve a hacer en público”. Por dinero en dólares, gente de varias edades (ningún viejo, ningún niño) se atreve a dejarse ver sin adjetivos. Ninguna coartada emocional los protege lo suficiente. El público se relaciona con porciones de intimidad observadas en proporción inversa a su entendimiento. La premisa es compartir vulnerabilidades de manera interactiva. Ante los ojos circula información confidencial de los protagonistas, quienes nada hacen por ocultar la repetida desorganización de sus comportamientos.

Dentro de la ficticia casa todos viven con espléndida felicidad una situación anormal, como si ante el televisor la vida fuera más fácil: treinta cámaras en todos los idiomas, Big Brother, Gran Hermano, Grande Fratello, Grosset Bruder, Grand Frère, retratan la diversión de último momento. La ubicuidad tangencial de las cámaras ha roto la tenue línea entre realidad y entretenimiento. La desprotección de las pruebas de intimidad magnificaron la experiencia del ojo, trasladando el lugar persuasivo de la sugestión a la evidencia. Esa experiencia visual es prolongada con la insistencia de aquellas cosas que no terminan de 
cumplirse, pues el incumplimiento las define: entramos en la intimidad de unos extraños que al poco tiempo resultan familiares, aunque la entrada nunca se completa, siempre falta algo. Mejor dicho, nada falta, todo sobra. La gran recompensa de Gran hermano no es el premio final en dólares sino los días vividos frente a una cámara de televisión. Los minutos de fama son algo más de quince como creía Andy Warhol, suman varias semanas. Para el ego representa un viaje a las estrellas. Propuesta de indecencia ad infinitum.

No obstante, por la falta de ideas y comportamientos originales, la impostura termina originando una insoportable monotonía. Las situaciones repetidas desensibilizan el contenido en relación directa a lo previsibles que se van haciendo las circunstancias. La apariencia queda desprotegida una vez que la intimidad televisada se convierte en lugar común pisoteado por la mirada de millones. La prisión de la mente adquiere una visualidad desgastante, en cuanto las ansiedades privadas pierden independencia. Dejan pronto de ser anónimas y su respuesta ante la práctica intrusiva es muy simple: nada complejo hay más allá de lo que puede verse. Televisión fisiológica, en cuanto sale de los reclamos de ficción para instalarse en un porvenir realista (esa es su nueva forma de generar ficciones) donde cada escena pretende convertirse en registro de algo inesperado que no se realiza.

En la preservación del simulacro de confinamiento, los habitantes reemplazan la vida en exteriores por una intimidad entregada en plazos. La carnada de la curiosidad los convierte en héroes de un acto de condescendencia que supera la calamidad del espectáculo. Lo que está en juego es la definición de persona a través de la eficiencia del grupo. Como en Los tres mosqueteros, son todos para uno y uno para todos, hasta que el todo termina siendo el borramiento de la persona única, de las actitudes singulares. Hasta los nombres resultan inservibles, datos inexactos de un comportamiento que nada tiene de mutuo. El proceso de pérdida de la anonimidad tiene pues una condición erosiva, en tanto se crea la ficción de que ningún motivo queda escondido ni puede esconderse. La identidad es grabada desde todas sus inconveniencias: la vida en vivo y en directo pasa por un tape que no tiene salida (un tape sin destape), ni siquiera cuando la acción es rebobinada.

Los habitantes llegan a ser conocidos por acopio de detalles, estableciéndose un proceso autobiográfico que se cumple en varias semanas continuas de escrutinio. La impunidad del ser invisible queda perdida en el precario y desarticulado modelo de una identidad con las puertas abiertas. Autobiografías autorizadas que se confunden con el constante fluir de información acumulada, proveniente, al menos en apariencia, del lugar normal de la vida. Efecto de una tiranía ejercida con consentimiento, la mirada entra en las respuestas esperadas del repertorio humano como si fuera un laboratorio animal. El grupo deviene una entidad abstracta dividida en nombres diferentes, cuya dinámica pretende construir un propósito. La coartada del ejercicio panóptico tiene un destino asimétrico: hace creer al observador — uruguayo o de donde sea— que mirando "conoce" a los protagonistas y que esa contemplación demiúrgica —en tanto está sucediendo al mismo momento en que se ve- enmienda el conocimiento o desconocimiento de los seres observados.

Experimento social/antropológico que imposta un sentido de verosimilitud, Gran hermano presenta evidencias contrarias a la ficción caracterizante de los programas de televisión, pues aquí no hay libreto ni pautas de desarrollo: la fuerza motriz es el comportamiento de los personajes, el trabajo de su desinhibida performance. Por lo tanto, 
si estos no resultan interesantes, como ha sucedido con todas las versiones hasta ahora, el programa fracasa. La interacción episódica entre ideas y actitudes se queda en un intersticio sin ocupar, en la franja que va de la anticipación a lo previsible. En esa realidad emocional convencional que aspira a ser tenida como documento, la imaginación del espectador queda librada a lo previsible, quitándole toda responsabilidad a lo que pueda suceder posteriormente. De todas formas - aunque el programa se mueve con una única forma-, sólo pasan cosas que se espera que pasen. A través de rutinas consecutivas, dosis mayores de "todos los días lo mismo", se ritualiza el aburrimiento, pues al reivindicar comportamientos interesados en hacer creer que en la nada pasan cosas, el tedio adquiere un semblante de validez y condescendencia. Las grandes cantidades de tiempo que transcurren dentro de la casa activan el lado inactivo de la nada y ésta, a pesar de su insistencia, nunca podrá ser una forma de arte. En todo caso, sera un shock vulnerado por la predecible trayectoria de sus ilusiones.

En 1984 (novela de 1948) George Orwell imaginó una sociedad hipertecnificada donde el aparato de gobierno podía controlar todas las acciones. Era un monitor permanente denominado Gran hermano, cuyo ejercicio totalitario podía dominar la mente incluso en sus más privados remansos. El ojo avizor desmantelaba las posesiones de la intimidad, permitiendo que el vandalismo silencioso se apoderara del comportamiento, como si un hacker entrara en el portal de un secreto y lo hiciera suyo. El cine, que suele llegar a todo antes que la televisión y después que la literatura, había realizado con anterioridad varios ejercicios de comportamiento totalitario: The Truman Show y EdTV, y previamente Doble de cuerpo, y aun antes La ventana indiscreta de Alfred Hitchcock, obra maestra. En todas ellas la premisa, con mínimas variantes, era la misma: espiar al otro todo el tiempo para dominarlo mediante el control remoto de la observación ("El infierno son los ojos que nos miran”, dijo el filósofo, y aquí la mirada construye su limbo: solamente la indiferencia puede salvarla).

También la aspiración de los productores de Gran hermano es omnisciente: filmar de principio a fin la vida que cabe en un programa de televisión. Ficción de intereses dispersos que sacrifican su continuidad a cambio de otra que les presta más atención. Similares a astronautas en una cápsula espacial que es vista en simultáneo por el resto de los terrícolas, los protagonistas se someten a la mirada policial que los encuentra en su peor desprotección. Son disecados mientras la actividad sigue ininterrumpida. Para la cámara no hay límites de incomplacencia. Lo mismo da el toilette que el living, la noche que la mañana. Si ellos representan a la raza humana, los espectadores, viéndolos tan de cerca, se sienten husmeadores de sí mismos. Es la diversión del futuro (por más que éste ya no sea como antes), es la entrada al gran entrometimiento. Televisión sin imágenes perdurables, galvanizada por el confort de las circunstancias. De tanto intentarlo y repetirlo, el nonsense legalizó su procedimiento. La moraleja que queda a la vista — porque aquí todo está a la vista - es tan pobre como su propuesta. Viendo que otros tienen una vida más miserable y aburrida que la nuestra sentimos que la televisión nos redime. Pensamos: después de todo no estamos tan mal. 
II. No Llores tANTO POR Mí Argentina

Una joven esbelta, de esas que dan ganas, se pone a llorar desconsoladamente porque le informan que ha sido nominada. Llora como si la hubiera dejado su futuro novio. ¡Qué extraño!, en Hollywood cuando alguien es nominado ríe y celebra. Pensé inmediatamente que los argentinos, al menos los que caben en un televisor, son en verdad gente triste como la del tango y celebran una nominación llorando. Luego vine a saber que no era una nominación para el Oscar sino otra, sin estatuilla. Una por la cual al favorecido lo echan de una casa donde hay más seres humanos, todos los cuales lloran cuando son nominados. Hay desalojos. ¿Qué habrá en esa casa que nadie quiere abandonar? La joven lloraba porque quería quedarse. Un alma contra la diáspora. Yo vi a gente en situación similar, llorando incluso más pues la desalojaban de su casita por no poder pagar las mensualidades de la hipoteca. Pero Gran hermano es un juego. En todo caso, es un juego donde hay que adivinar qué tipo de juego es. Para quien piense, no resulta divertido. Tal vez lo sea para aquellos que pueden permanecer en la casa sin ser nominados. La casa de la ficticia fraternidad queda convertida, por arte de cámaras, en un sumidero sin enigmas donde una parvada de humanos se aísla de la realidad y del pensamiento.

Dentro se oyen conversaciones al borde de la anemia que ilustran el peor tedio posible, aquel donde el lenguaje está agotado y las palabras no refieren a ningún sentimiento o decisión; flotan como ruido, como fin sin finalidad. Allí las ideas perdieron su turno para siempre. No hay posibilidad de réplica. La única preocupación metafísica de los habitantes es que nadie los nomine; una meta física. Autocongratulan la carencia de intelecto a través de la continua refutación del mismo: una degradación de los contratiempos. La situación no está nada mal; les regalan la comida y viven sin trabajar ni tener que pagar la renta. Lo único que deben hacer para que no los expulsen enseguida, es actuar como retardados las veinticuatro horas del día. Eso no supone un problema pues así actúan en su casa verdadera (por la que sí deben pagar alquiler). En total pasan ciento doce días libres de gastos, enseñándole — gratis - a los televidentes cómo ser estúpidos sin tener que abandonar su casa. Un sedentarismo extremo y ficticio en tiempos de vidas nómadas. Los protagonistas eligieron el confinamiento como táctica para escapar del anonimato; el suyo es un oportunismo al alcance de la mano.

Pese a ser un mal ejemplo para la inteligencia, Gran hermano argentino ha sido un gran éxito de público. La gente lo mira, lo comenta y lo vuelve a mirar al día siguiente. Como no pasa nada, todos se sienten protegidos. Este tipo de suceso no debe sorprender a nadie. En Roma, la multitud se peleaba por entrar al Coliseo para ver a los gladiadores despedazarse. Celebraban rabiosamente al ganador, quien tarde o temprano terminaba muriendo. Las victorias no se apiadan de la mortalidad. Eran tiempos paganos y estos, nada sagrados, pagan al último en ser desalojado dinero en dólares. El juego tiene una premisa básica: las cámaras ejercen una vampirización (de la intimidad ajena). Además de SIDA, epidemia de voyeurismo. Aunque, cabe decirlo, se implanta una farsa, un simulacro de espontaneidad, en tanto los protagonistas pasaron un casting previo, saben que están siendo vigilados y modifican su comportamiento para ganar el favor del público, que terminará eligiendo al ganador. A los otros, los votan y los botan. Cuando sí, lloran porque no quieren (desped)irse. Lo mismo que en un teleteatro reprobable pero sin guión, es decir, mucho peor. 
Estos actores, protagonistas de sí mismos, nada tienen para decir, por lo tanto no hay drama ni desempeño emocional. Se trata de un torneo de bufones donde el público debe seleccionar a aquel idiota que le resultó más complaciente (emite su voto por teléfono); una democracia perfecta: todos pueden sentirse comprometidos con la imbecilidad de los otros. Gana aquel menos diferente pues nadie puede ser más real que los demás. Orwell imaginó una identidad superior controladora, pero aquí, en el frenesí de la interactividad, los fisgones somos todos, esto es, nadie queda a salvo. La paradoja cumple su ciclo: espiando creemos vernos desde fuera. Todos somos extraños en el proceso de serlo.

Buscando alguna frase interesante que nos/los redimiera, por una semana entera sintonicé el programa. No pude encontrar ninguna. Subí varias veces el volumen del televisor, pero ese no era el problema. Retorné la semana siguiente y hallé igual cantidad de oraciones inservibles, pero menos gente: un nominado había recibido el premio de la expulsión. Lloraba. Parecía Gwyneth Paltrow cuando le dieron el Oscar. Pero éste era él. También lloraba. Los televidentes uruguayos piensan, nuestros (grandes) hermanos argentinos son muy emocionales. Cambié de canal: vi más programas, uno en el cual también había gente, otro deportivo, y un tercero donde había policías y bandidos. Pasó un rato largo, como varios minutos. Volví a Gran hermano y el expulsado seguía llorando. Temí que algo le pasara antes de que llegaran los avisos comerciales. Quienes permanecían en la casa reían como si se hubieran sacado la caspa de encima. Uno fuera, qué alegría. Extraña hermandad. Cuantos menos, mejor. La locutora flaca le preguntó al expulsado: “¿Cómo te sentís?” La conductora, Soledad (Silveyra), quería acompañarlo en la suya, soledad. Las preguntas que hacía estaban al nivel de los participantes: ninguno debía pensar para responderlas. Televisión sin prioridades (en un medio trivializado, el mensajero no siempre tiene relación con el mensaje).

En un pacto de exhibicionismo, los participantes dejan entrar a los espectadores en su acelerado desear. Los objetos de sus deseos se llaman fama, popularidad y dinero; hay gente que por eso es capaz de matar o, todavía peor, de actuar como verdaderamente es. Tienen confianza en el éxito y encuentran beneficios en las ruinas del comportamiento. Ante millones de miradas se desmoronan ética y estéticamente, sin compasión consigo mismos. La vida sigue teniendo el consentimiento de lo precario y a su condición se entrega. Los ejemplos entran y salen de la pantalla, rastreando el sitio efímero de una historia y sus conductas. Si la televisión sigue funcionando con normalidad, dentro de muy poco será recompensada con un Gran hermano más violento, mezcla de gladiadores y corridas de humanos en lugar de toros. Para entonces no será mala idea dejar a los participantes adentro, sin comida; sólo sobrevivirán aquellos que se reciban de Hannibal Lecter. Quien gane tendrá como premio la vida; los demás quedarán en la casa para siempre.

Por el momento, la mayoría se siente entretenida. El aburrimiento del formato actual resulta lo suficientemente entretenido como para no tener que cambiar de canal. Traspasando los límites de la oligofrenia, la idiotez y el confort actúan simultáneamente, ya que los involucrados se ponen de acuerdo para no pensar más de lo que no pueden. Surgen evidencias de cooperación entre seres contrarios a la realidad a pesar de permanecer en ésta. En ese diagnóstico de situaciones, el grupo siente y habla frente a las cámaras sin otra 
novedad que el transcurrir de un tiempo muerto. Ningún goteo de inteligencia. Incluso los que intentan complacer a Gran hermano fracasan; en el interior de la casa hay gente sin vida interior. No tienen nada para decir ni decirse y no saben decirlo. En síntesis, don nadies con el coeficiente mental de ninguno. La nada a punto de ser completa. El tiempo sin acción, la morosidad lírica del pensamiento, que Tarkovski y Joyce convirtieron en lenta complacencia de bellezas, aquí es cómplice de una nada con planes diferentes. El vacío es su propósito.

En uno de los primeros programas la locutora flaca informó que todos los participantes de Gran hermano eran gente normal. Ambigua definición de normalidad. También los vecinos de los asesinos en serie dicen que todos parecen normales y se muestran incrédulos al saber de sus aberraciones. Cuando Orwell escribió 1984, el mundo mostraba los primeros síntomas de una anormalidad diferente. El escritor inglés llegó temprano al presentimiento de un miedo que iba de todo a todos. Imaginó que el poder, para poder mantenerse, debería espiar las ideas de una civilización cada vez más inteligente. Se equivocó. No hay nada para preocuparse, nada para espiar.

Según los grandes hermanos españoles y argentinos, el ser humano es destinatario de su idiotez y como tal vive, en su propia casa o en una prestada. Espiarlo, por lo tanto, es un ejercicio innecesario. Para futilidad basta lo que somos. Entre dilemas, algunas pausas de lascivia, teatralidades y romances imposibles, aparecen farfullando almas atormentadas por la falta de promesas, gente que no se reduce a un solo adjetivo ¿Qué espiar donde no hay ideas, ni diferencia, ni sensibilidad sino comportamientos rutinarios prontos a enajenar y a no dejar ajenos? ¿Qué? Diletantismo nada episódico, Gran hermano crea la ficción de que todos los límites son transgredibles: espiar a alguien bañándose limpia el aburrimiento, expulsarlo de la casa resulta un miniaturizado ejercicio de poder (una forma de desterrar). Todo puede transgredirse, todo menos ciertas excepciones ocurridas en el acto de la recepción, escépticas y desencantadas ante los ingredientes de negatividad de una caterva de conductas. Una logia sin ontología.

Tan aborrecible como la vacuidad de Gran hermano es la laxitud de los opinadores de turno, esgrimiendo el simplista argumento, “a la gente le gusta”. Pronto el público se cansará de ver intimidades transpasadas y querrá algo más, como quiso antes, disfrutando las ejecuciones públicas, las matanzas colectivas y las ideologías. Sin estar obligados salían a las calles a vivar a Hitler y Stalin, con los mismos gritos de algarabía que antes, al pie de patíbulos y guillotinas, destinaban fácilmente a los verdugos. Es que siempre ha sido fácil seguir el ejemplo contrario. Apenas ha cambiado una cosa: hoy la comodidad del espectáculo requiere menos remordimiento.

III. Los hiJos de LA Madre PAtria

En una época nueva, cuando el tema del mundo (a partir de la formulación del mapa del genoma humano) son los genes, apareció un nuevo gén(ero) televisivo, los reality shows. La globalización de las expectativas trajo un ejemplo mal aconsejado: Gran hermano. Especie de docuteleteatro donde gente aburrida trata de ser divertida y busca celebridad a partir de la constancia de las superficies. Gente que se siente confortable en el lugar de observación, pues allí el talento es innecesario. El insecto no debe hacer un 
show bajo el microscopio: sólo debe ser. La fórmula del programa quiere parecerse a la índole de un acontecimiento, pero irremediablemente queda incumplida.

En las tiendas se observa por circuito cerrado a la gente comprando. Aquí el ojo entra en otro tipo de dominio, pues el circuito está abierto. Un clic en el control remoto permite abolir la privacidad. Un clic autorizado, ya está. Es extraño: encender el televisor y encontrarse en medio de la vida ajena, antes no pasaba. Asuntos privados convertidos en tema colectivo sin otra razón que perder el tiempo, la expansión residual de éste. Vaya ironía, el spleen confía en el prozac de la tecnología. Así están las cosas: el público está obsesionado con lo banal, y Gran hermano representa la última recompensa a sus afanes. Una cura ante la falta de locura.

Para poder sobrevivir, los protagonistas debieron ser lo que son, aunque todavía no lo saben. La primera respuesta fue apresurar el intangible conflicto con el otro, participar en un enfrentamiento como si fueran gladiadores con espadas de goma. Sin una idea superior que los convierta en ficción, aceptaron el inferior encanto de la apariencia, transcurriendo hacia afuera, hacia el semejante incompleto que todo el tiempo prefirió quedarse en ese estado. Pronto, ante el fracaso de las expectativas, el espectador se sintió fuera de aquello que los personajes no pudieron mostrar porque no tienen. Esto es, al principio nadie sabía lo que iba a pasar, luego todos sabíamos demasiado. De la expectativa al desinterés en un lapso breve. Si esto es entretenimiento, la espera en el consultorio del dentista también lo es. En poco tiempo, como si se tratara de un virus rápido y mortal, los televidentes se sintieron poseídos por la estupidez ajena y las ganas de existir incompletamente. Un ántrax audiovisual. Pero no se compara, pues para hablar de Gran hermano hay que usar el “como” de otra manera. El programa sólo es como él. El colmo del "como".

En Gran hermano, la indolencia resulta un mal inexplicable. Indolencia como apatía, como colmo para insensibles. Como diagnóstico de una realidad obsesiva donde la interacción entre la nada y su presencia es lo único genuino. Para satisfacer la curiosidad, que mató al gato pero no al ser humano, siete días a la semana la televisión entró en un hogar hipotético pero reconocible: igual que a los enanos, a los idiotas se les reconoce desde lejos. Podrán estar en Madrid, pero igual se les puede observar desde el sofá del living. Se convirtieron en famosos por razones que nadie sabe —el rating no las da-y salieron del acontecimiento sin que nadie los necesitara. Tuvieron varios sinónimos: tontos, idiotas o mentes en condición precaria que fuera de cámaras podrían pertenecer a otra especie. Una sociedad sin saciedad. Un extraño caso de redundancias. El lifting televisivo les quitó edad: cada uno de los españoles parecía tener treinta años pero aún no superaron la etapa infantil. Cuerpos cuya edad mental es menor y que aprendieron a existir sin necesidad de pensar, es decir, sus acciones no dependen de la inteligencia. En su versión adolescente, con voces, gestos y perspectivas reducidas por el comportamiento, resultan a la postre personas salvaguardadas de la edad adulta.

Por semanas seguidas se vio movimiento dentro de la enorme jaula humana en Madrid, un garaje del comportamiento (no para repararlo, para verlo), un atajo hacia la nada, a través del cual aparecieron personas buscando atención. Los efectos de la intrusión, el escrutinio del otro que se atreve a confesarse sin proteger su información, cruzaron la barrera de lo previsible. Por más que la jaula era transparente como vidrio, la 
botella al mar fue enviada esperando una respuesta que llegó sin firma: el televisor protege al menos a los fisgones. La pantalla fue un balcón para verificar destinos con desatinos. Un espejo de conductas donde pudo verse la civilización en estado popular: una mala imagen. En la casa, durante ese tiempo, no crecieron plantas, sino la necesidad de fama de gente inculta reunida por los mismos objetivos, ninguno, salvo ganar el premio: hablar sin recompensa. Vivían en una frase transicional que nunca abandonaban ni los abandonó. Puesto que nada de lo que dijeron importa, todo tuvo validez. En ese conflicto conversacional, la lingua franca de la oligofrenia remueve la indiferencia; nadie queda ajeno a la lección de tedio que llega con todos sus elementos (un beneficio social).

En el plazo que les tocó estar debajo del microscopio, estos legionarios de la banalidad fueron coherentes con sus carencias, aburriendo con sus conversaciones hasta al propio lenguaje. Ya que no tienen nada para decir, querían ser inentendibles (con España nos separa algo más que un montón de agua). Pasaron de la falta de cautivación al desinterés, imposibilitando el acto de las palabras. Estas fueron víctimas de la deriva de sinsentido y de un actuar en ella que buscó tener repercusión en las cosas más insignificantes que lo definen y que, para el caso, fueron mayoría. Al tercer día, la pregunta era absoluta: si en la intimidad son tan estúpidos, ¿cómo serán en la extimidad, en la vida de afuera? Convertidos en microcelebridades, con sus personalidades empeoradas, esto es, más atontadas, los protagonistas del Gran hermano español apenas buscaron ser tenidos en cuenta por lo que querían ser. Rara forma de estar en el ser. To be or not to be (vieron tiempo pero no llegaron a nada), hasta que dejaron de estar. El rating carece de exigencias y permite una existencia libre de responsabilidades. Si los números crecen como crecieron, la vida encontró entonces un orden al cual atenerse; su éxito depende de cifras de nadie y de nada para descifrar.

Imitando a las tortugas que abandonan su caparazón para salir a morir en la intemperie, estos obvios candidatos al olvido exponían diaria y nochemente las carencias de su personalidad a cambio de poder hacer lo que ansiaban: ser vistos sin tener nada para mostrar. Probaron que la mirada también puede sufrir amnesia y por olvidarse sufrieron la humillación de ser expulsados por voto popular, pero antes hicieron todo lo posible para justificar esa decisión. Algunas de las malas virtudes de la civilización occidental aparecieron resumidas con fidelidad en este Gran hermano ibérico, igual en sus aspiraciones al rioplatense. La noble responsabilidad del entretenimiento (hacer olvidar que el tiempo pasa igual para todos) quedó arruinada antes de que el futuro imperfecto se cumpliera. A quién le puede preocupar la felicidad ajena cuando los involucrados se jactan, sin saberlo, de su falta de propósitos. Todavía no apareció el antídoto contra tanta vacuidad. Nadie de la audiencia salió conmovido con estos humanos sin características de tales y los que salieron (expulsados) difícilmente tendrán en la realidad el destino del hijo pródigo. Con una vez ya fue bastante.

La expresión sociedad civilizada encuentra en el adjetivo una excusa, pues no siempre una sociedad lo es. ¿Es civilizado espiar a seres humanos incompletos que, a falta de interés en la vida, se dejan espiar? Espiar y expiar se parecen, pero la expiación de los espías que todos somos nunca llegó a cumplirse. La vida como performance se convirtió en motor de un monitoreo en el fondo del cual los participantes derrotaron a la sensatez 
con su infantil comportamiento. No aprendimos nada. (Podrá argumentarse con toda validez que, por pudor, frente a las cámaras fueron menos idiotas que de costumbre; puede ser.) Dentro de la casa hubo gente y dentro de los personajes, nada. El rito siguió los pasos de una frustración paulatina. Las técnicas de supervivencia incluyeron la exageración del sinsentido, la autoparodia (de manera involuntaria) y la neurosis por haber sido únicamente eso: marionetas de una pretensión inconclusa. Terminarán siendo ignorados con exuberancia, pues el paso de nadie a alguien fracasó.

Queda claro: para la era esta, la intimidad ya no es un refugio de secretos; se perdió la quimera del anonimato. Millones de voluntarios lo quieren así. La privacidad tiene otro sentido. Ya no es la misma de antes cuando la máxima intrusión que podía perpetrar una persona era entrar en el jardín del vecino. 